\title{
Divisions of the Abhisamayālañkāra
}

\section{THE KNOWLEDGE OF ALL MODES}

1. The varieties of the thought of enlightenment 45

2. Instructions 56

3. The Aids to Penetration 95

4. The lineage or the source of progress 117

5. The objective supports $\quad 120$

6. The program 123

7. The progress which consists in putting on the armour 128

8. The progress in setting out 131

$\begin{array}{ll}\text { 9. The equipment } & 137\end{array}$

10. The progress which consists in going forth 182

\section{THE KNOWLEDGE OF THE PATHS}

1. The limbs of the knowledge of the paths

2. The knowledge of the paths which consists in the cognition of the path of the disciples

3. The knowledge of the paths which consists in the cognition of the path of the Pratyekabuddhas

4. The path of vision and the great advantage 216

5. What the path of development does 227

6. Resolute Faith 230

7. Praise, eulogy, and glorification 256

$\begin{array}{ll}\text { 8. Turning over } & 269\end{array}$

9. Rejoicing 281

10. Glorification of the marks of consummation 283

11. Absolute purity 287

\section{ALL-KNOWLEDGE}

1.-2. Unestablished in either Samsara or Nirvana 298

3.-4. Farness and nearness of perfect wisdom 298

5.-6. Points to be shunned and Antidotes 298

7. The endeavours of the cognition of entities 302

8. The sameness of the endeavours 305

9. The path of vision 305

(10. The résumé of I-III) 309 
xviii DIVISIONS OF THE ABHISAMAYĀLAṄKĀRA

IV. THE FULL UNDERSTANDING OF ALL MODES
1. Modes
2. Endeavours
3. Qualities
4. Faults
5. Marks
6. The aids to emancipation
7. The aids to penetration
8. The community of irreversible Bodhisattvas
9. The identity of Nirvana and Samsara
10. The purity of the Buddha-field
11. Training in skill in means

V. THE FULL UNDERSTANDING AT ITS SUMMIT

1. Its characteristics

2. The growth

3. Firm position

4. Complete stabilization of thought

5. The path of vision

6. The path of development

7. The unimpeded concentration

8. The sixteen errors

VI. GRADUAL REUNION

\section{THE SINGLE-INSTANTANEOUS REUNION}

1. With regard to all dharmas without outflows and without karma result

2. With regard to all dharmas without outflows which have reached the state where their karma result has matured

3. The single instantaneous reunion which sees all dharmas as devoid of marks

4. The single instantaneous reunion which sees the mark of nonduality in all dharmas

\section{THE REUNION WITH THE DHARMA BODY}

1. The substantial body

2. The enjoyment-body

3. The transformation-body

4. The work of the Dharma-body by means of the Transformation-body-in general

5. The functions of the Dharma-body 